
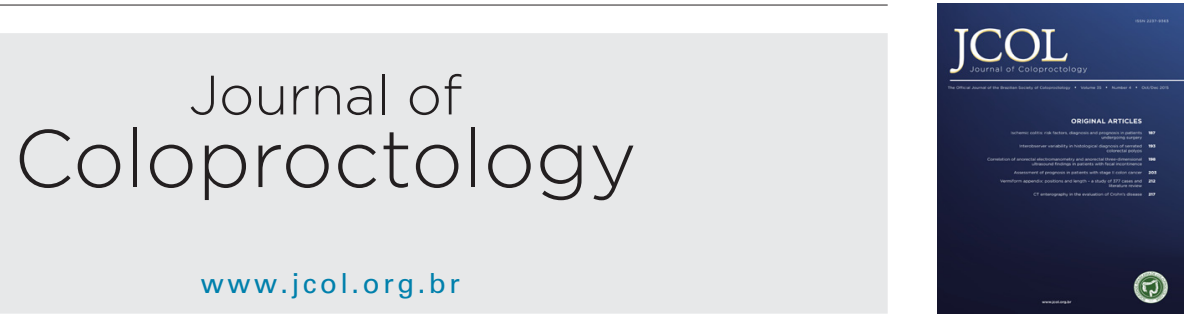

\title{
Special Article
}

\section{General recommendations to the colorectal surgeon during the COVID-19 pandemic}

\author{
Fábio Guilherme Campos (10), ${ }^{a, *}$, Henrique Sarubbi Fillmann (10 $b$ \\ a Universidade de São Paulo, Hospital das Clínicas, Divisão de Cirurgia Colorretal, Departamento de Gastroenterologia, São Paulo, SP, \\ Brazil \\ b Universidade PUCRS, Faculdade de Medicina, Departamento de Cirurgia, Divisão de Cirurgia Colorretal, Porto Alegre, RS, Brazil
}

\section{A R T I C L E I N F O}

\section{Article history:}

Received 1 June 2020

Accepted 10 June 2020

Available online 19 June 2020

Keywords:

Coronavirus

COVID-19

Colorectal surgery

Coloproctologist

\section{A B S T R A C T}

The COVID-19 pandemic has shown our country in an unfavorable light, as Brazil has reported the second highest number of deaths to date. When the social isolation phase is finished, professional activities (including the medical ones) will resume their routines and the specialist must be updated in order to provide effective and safe care. Although many published recommendations are based on low levels of evidence, disclosing them has become necessary, since the coronavirus infection may affect operative outcomes. Overall, it is suggested that physicians adopt preventive measures, starting with the medical appointment, and extending them to the surgical procedure. Furthermore, it is also necessary to provisionally change criteria for operative indications and conducts. Currently, postponing elective surgeries seems to be a universally agreed decision. Moreover, we need to establish the early diagnosis of the viral infection, before or after the surgery. Several safety measures related to minimally-invasive procedures have been reported, disclosing the risks of aerosol dissemination by the pneumoperitoneum and smoke from energy-powered devices. The present article aimed to bring to the colorectal surgeon the current recommendations and general safety measures in order to prevent infection dissemination, to improve surgical planning in terms of timing and specific technical aspects.

( ) 2020 Sociedade Brasileira de Coloproctologia. Published by Elsevier Editora Ltda. This is an open access article under the CC BY-NC-ND license (http://creativecommons.org/ licenses/by-nc-nd/4.0/).

\section{Recomendações gerais ao coloproctologista durante a pandemia do COVID-19}

R E S U M O

A pandemia pelo COVID-19 colocou o Brasil hoje numa situação de destaque negativo, porque somos o segundo país com maior número de casos no mundo. Ao finalizarmos o período de afastamento social, as atividades profissionais, incluindo as médicas, serão
Palavras-chave:

Coronavírus

COVID-19

Cirurgia colorretal

Coloproctologista

\footnotetext{
* Corresponding author.

E-mail: fgmcampos@terra.com.br (F.G. Campos).
}

https://doi.org/10.1016/j.jcol.2020.06.001

2237-9363/@ 2020 Sociedade Brasileira de Coloproctologia. Published by Elsevier Editora Ltda. This is an open access article under the CC BY-NC-ND license (http://creativecommons.org/licenses/by-nc-nd/4.0/). 
restabelecidas, e o especialista necessita estar atualizado a fim de prover o melhor nível de trabalho, de maneira segura. Apesar de muitas das recomendações estarem baseadas em opiniões e estudos sem muito grau de evidência, sua divulgação nesse momento tornase necessária, uma vez que a infecção pelo coronavírus afeta os resultados operatórios. De maneira geral, o médico deve assumir medidas preventivas desde o momento em que agenda uma consulta até a realização do procedimento cirúrgico. Além disso, é necessário considerar a necessidade de mudar provisoriamente os critérios de indicação cirúrgica, e até as condutas operatórias. Parece existir um pensamento uniforme no sentido de adiar cirurgias eletivas. Da mesma forma, devemos reconhecer a infecção viral precocemente, antes ou após a cirurgia. Diversas medidas preventivas relacionadas aos procedimentos minimamente invasivos já foram descritas, realçando o poder de disseminação pelo aerossol gerado nesses procedimentos e no uso de instrumentos de energia. O presente artigo visou apresentar ao coloproctologista as recomendações atuais e cuidados gerais para prevenir disseminação da infecção, e como planejar o tratamento cirúrgico com mais segurança em termos de momento da cirurgia e aspectos técnicos específicos.

(c) 2020 Sociedade Brasileira de Coloproctologia. Publicado por Elsevier Editora Ltda. Este

é um artigo Open Access sob uma licença CC BY-NC-ND (http://creativecommons.org/ licenses/by-nc-nd/4.0/).

\section{Introduction}

In humans, coronaviruses (from the RNA family) cause respiratory infections, such as influenza or severe syndromes (MERS, Middle East Respiratory Syndrome; SARS, Severe Acute Respiratory Syndrome). Since its appearance in China, in December of last year, the infection caused by the new coronavirus, SARS-CoV-2 (known as COVID-19), has spread rapidly and was declared a pandemic by the World Health Organization (WHO) in March of this year. ${ }^{1}$

The disease spreads from person-to-person through droplets from the nose or mouth through speech, coughing or sneezing, or when people come into contact with contaminated objects and puts their hands on their eyes, nose or mouth. Other forms of transmission are being studied. Once infected, the average incubation period is 5.2 days (2-14 days), and the individual may remain asymptomatic or develop flulike, general symptoms (weakness and body pain), digestive and other symptoms. While the vast majority recover without difficulties, around $1 / 6$ of the patients can have the severe form of the disease, especially elderly individuals or those with comorbidities. $^{2}$

It is currently known that, in addition to the profound pulmonary effects, there are digestive, neurological, renal and other alterations associated with the viremia. More than the infection itself, the health system is deeply affected, and the economic consequences are estimated to be devastating in the short term.

In Brazil, the pandemic reached numbers compatible with our large population, making it one of the five countries with the highest number of diagnosed cases. During the course of the pandemic and soon after it has waned down, it is expected that practical activities will be routinely reestablished in all specialties. Consequently, several medical Collegiates have been concerned about discussing general recommendations for daily practice, even if it is based on the small number of published studies with a low level of scientific evidence. This attitude arises from the specialists' need to feel minimally safe and instructed to develop their activities. ${ }^{3-8}$

Therefore, colorectal surgeons need to adapt their practical activities to the new reality, considering the concerns related to the possibility of fecal transmission of the virus. ${ }^{9}$ In view of the several anticipated and expected changes in patient care, this report aimed to discuss the several recommendations published so far in our specialty.

\section{Suggested adaptations in outpatient care}

Many publications have suggested that when making an appointment, the patient should be asked about symptoms and contacts with possible carriers. When there is any cause for suspicion, the appointment should be postponed or carried out by telemedicine, reducing the risk of cross-infection. Patients should be advised to come without companions, if possible, and appointments should be scheduled at longer intervals, to avoid contact with many people. Alcohol gel must be made available in the environment, which must be regularly ventilated and cleaned.

The contact with patients should be made with the use of gloves, and both the doctor and the patient should wear facial masks, in view of the possibility of occupational exposure and cross-infection even by asymptomatic carriers. ${ }^{4,6,7}$ In spite of the criticisms, the use of telemedicine has received support due to the fact that it minimizes the risk of contact and exposure of the patient.

The Gastrointestinal Tract (TGI) is another target of SARSCoV-2, a fact recognized by digestive symptoms and the presence of the virus in the stool. This is probably due to the high expression of ACE2 (angiotensin-converting enzyme) receptors by enterocytes, also present in the type II alveolar epithelium. ${ }^{10}$

Symptoms in the high and low GIT are common, although diagnosed later, with watery diarrhea being the most frequent one $(20 \%)$, even in the absence of cough, shortness of breath, 
sore throat or fever. Diarrhea can occur before or after the respiratory symptoms, especially among women, and lasts an average of 5 days (1-14). Other complaints are nausea, vomiting and abdominal pain. The presence of GIT symptoms increases the chance of testing positive for COVID-19 and the disease duration. ${ }^{11}$

As much as possible, we must differentiate between uninfected, potentially infected individuals and sick patients, aiming to differentiate treatment strategies. In COVID+ patients, the treatment of respiratory symptoms must precede the oncological therapy (except in emergencies). Patients with suspected disease must be observed and kept in isolation. The management of non-infected individuals must include protection for the team, considering the incubation period of the disease. Thus, the preoperative screening process is essential to avoid nosocomial infection and to reduce individual risks.

\section{Should elective surgeries be delayed?}

While there is an increasing number of new cases and deaths, there is a recommendation to delay elective surgeries (including selected cancer cases) in order to provide medical resources and beds (including ICUs), increase the hospital areas that can be used, concentrate hospital activities for emergency care and, mainly, reduce the chances of crossinfection of doctors, patients and visitors. ${ }^{5}$

The big question of the moment is: when to operate or when to delay? If the doctor and patient decide to have an elective procedure, an analysis should be made about the risk of acquiring an infection during the hospitalization period, whether an eventual COVID-19 infection might have an impact on the postoperative evolution and the consequences of longer hospital length of stay (contracting a secondary infection, isolation from the family, etc.). Likewise, we should discuss the best time to reschedule the procedure and the possibility of disease worsening due to this rescheduling. A multicenter study carried out in patients from 235 hospitals showed that pulmonary complications develop in $50 \%$ of those with perioperative infection, leading to significant mortality. ${ }^{12}$

Depending on hospital conditions, the treatment of perianal abscesses, selected cases of hemorrhoidal thrombosis, infected pilonidal cyst and anal fissure associated with a lot of pain are procedures that can be considered without great risks. An alternative is to perform outpatient surgery under local anesthesia. ${ }^{13}$ In any case, RT-PCR swab tests should always be performed. In suspected patients, utmost care should be taken when handling stool in the rectal ampoule. The use of N95 masks and devices to evacuate smoke in all anorectal procedures are recommended. ${ }^{14}$ Some professionals request a chest computed tomography $24-48 \mathrm{~h}$ prior to larger procedures. ${ }^{15}$

\section{General recommendations and care measures during surgical procedures}

Any procedure performed on a COVID-19-positive or suspected patient must be performed in a specific room. Appropriate PPE (N95 masks, caps, gloves, facial protection, eyewear) must be used by the team, who must be trained to remove it at the end of the surgery.

To operate on COVID+ or suspected patients, it is recommended that patients have an exclusive access to enter and leave the operating room. A minimum number of people in the operating room is recommended, and orotracheal intubation and extubation should be performed by the anesthetist without the presence of the surgical team in the operating room, preferably under negative pressure.

The indication of negative pressure is based on a history of infection by other pathogens, allowing the air flow to enter the room, but not its escape into neighboring areas. ${ }^{7}$

Regarding the energy units, the use of monopolar scalpels, ultrasonic dissectors and advanced bipolar devices should be minimized, in addition to using the lowest possible power for the desirable effect, aiming to reduce the occurrence of particle aerosolization. The use of monopolar diathermy pens, along with smoke evacuation, can be helpful to prevent inhaling by the team members and assistance. ${ }^{6}$

\section{Open, laparoscopic or robotic abdominal operations}

In a Minimally Invasive Surgery (MIS), there is a potential risk of aerosol dispersion along with viral particles, which is why there is controversy about using this access route in patients who may be infected. However, the detection of the virus in the peritoneal fluid in a COVID+ patient highlights the need for protection also in open surgeries. ${ }^{16}$ The decision regarding surgical access will then depend on the availability of MIS equipment and the detection of COVID-19 in a given patient. While closed procedures are safer, open ones can disseminate fluids and smoke more easily. Nevertheless, some believe that it is necessary to avoid laparoscopies due to the risk of viral spread during pneumoperitoneum. As this chance has not been well evaluated, the initial recommendations for abandoning MIS procedures quickly lost strength. ${ }^{6}$

It has been recognized that the benefits provided by MIS (shorter hospital stay, reduced complications, less contact with abdominal organs) are very useful in patients with possible respiratory function impairment, if they become infected. On the other hand, the release of aerosols during or after the end of the surgery can contaminate the environment. Even during a laparotomy, care must be taken to completely evacuate all smoke resulting from the use of diathermy/electrocautery, including the use of rooms with negative pressure. ${ }^{5}$

Generically, the main recommendations and care defended so far are listed here:

- Provide informed consent on the risk of exposure to the virus and its consequences.

- Adopt protective measures in open, laparoscopic or robotic procedures.

- Create pneumoperitoneum using the closed technique with Veress needle.

- Make tight incisions for portal introduction, to avoid the inadvertent passage of gases through the wall. 
- Maintain minimum inflation pressure during the procedure, which allows the creation of sufficient operating field (8-12 mm/Hg).

- The MIS procedure must use devices to evacuate and filter the released $\mathrm{CO}_{2}$ that may contain aerosol particles (AirSeal iFS ${ }^{\circledR}$ System or LaparoshieldTM Laparoscopic Smoke Filtration System).

Before making the assistance incision (to remove the specimen), before a surgical conversion or before removing the trocars at the end of the surgery, the pneumoperitoneum must be emptied by a filtration system, to avoid leaks. The trocar orifice must be connected to the negative pressure suction with a water seal.

As the virus can be present in gastrointestinal cells (saliva, intestinal contents, blood), endoscopic procedures must be considered of high risk and the same energy precautions must be adopted.

Procedures that require additional $\mathrm{CO}_{2}$ insufflation (endoscopic mucosal resection and endoluminal procedures) should be indicated according to strict criteria and maximum care until the viral aerosolization properties are better known.

It is recommended to use negative pressure also in endoscopic rooms. Endoscopies should not be performed in the medical office due to the risk of contamination of the environment and the need for special protective materials, and the cleaning of surgical or endoscopic material used in a positive or suspected patient should be done separately from others.

\section{Conflicts of interest}

The authors declare no conflicts of interest.

\section{REFERENCES}

1. Organização Mundial de Saúde (OMS):

https://www.who.int/news-room/q-a-detail/q-a-coronaviruses.

2. Ungaro RC, Sullivan T, Colombel JF, Patel G. What should gastroenterologists and patients know about 63 COVID-19? Clin Gastroenterol Hepatol. 2020;18:1409-11.

3. Morrell ALG, Tustumi F, Morrell AC, Ribeiro DMF, Corsi PR. Laparoscopic or robotic intraoperative management to minimize aerosol dispersion: adaptations to the context of the COVID-19 pandemic. Rev Col Bras Cir 47:e20202558.
4. The Society of American Gastrointestinal and Endoscopic Surgeons SAGES. Recommendations Regarding Surgical Response to COVID-19 Crisis 2020; Available from: https://www.sages.org/recommendations-surgical-responsecovid-19/.

5. Wexner SD, Cortés-Guiral D, Gilshtein H, Kent I, Reymond M. COVID-19: impact on colorectal surgery. Colorectal Dis. 2020 [Online ahead of print].

6. Francis N, Dort J, Cho E, Feldman L, Keller D, Lim R, et al. SAGES and EAES recommendations for minimally invasive surgery during COVID-19 pandemic. Surg Endosc. 2020;34:2327-31.

7. The American College of Surgeons. ACS COVID-19 and surgery; 2020. Available from:

https://www.facs.org/covid-19/clinical-guidance

8. The Royal College of Surgeons updated intercollegiate general surgery guidance on COVID-19; 2020. Available from: https://www.rcseng.ac.uk/coronavirus/joint-guidance-forsurgeons-v2/

9. Di Saverio S, Pata F, Gallo G, Carrano F, Scorza A, Sileri P, et al. Coronavirus pandemic and colorectal surgery: practical advice based on the Italian experience. Colorectal Dis. 2020, http://dx.doi.org/10.1111/codi.15056 [Online ahead of print].

10. Lamers MM, Beummer J, van der Vaar J, Knoops K, et al. Science. 2020, http://dx.doi.org/10.1126/science.abc1669 [2020] [Online ahead of print].

11. Han C, Duan C, Zhang S, Spiegel B, Shi H, Wang W, et al. Digestive symptoms in COVID-19 patients with mild disease severity: clinical presentation, stool viral RNA testing, and outcomes. Am J Gastroenterol. 2020;115:916-23.

12. Bhangu A. National institute for health research global health research unit on global surgery, heritage building, University of Birmingham. Lancet. 2020, http://dx.doi.org/10.1016/S0140-6736(20)31182-X.

13. COVIDSurg Collaborative. Global guidance for surgical care during the COVID-19 pandemic. Br J Surg. 2020, http://dx.doi.org/10.1002/bjs.11646.

14. Pantel HJ, Einarsdottir H, Reddy VB, Longo W. Should respiratory protection be used in all anorectal operations that generate smoke? Dis Colon Rectum. 2020 [Publish Ahead of Print].

15. Gallo G, La Torre M, Pietroletti R, Bianco F, Altomare DF, Pucciarelli S, et al. Italian Society of Colorectal Surgery recommendations for good clinical practice in colorectal surgery during the novel coronavirus pandemic. Tech Coloproctol. 2020;24:501-6.

16. COVIDSurg Collaborative. Mortality and pulmonary complications in patients undergoing surgery with perioperative SARS-CoV-2 infection: an international cohort study [published online ahead of print, 2020 May 29]. Lancet. 2020. S0140-6736(20)31182-X. 